\title{
Model-Based Analysis of Student Satisfaction in Open Distance Learning
}

\author{
M. J. R. Perera ${ }^{1}$ and N. Abeysekera ${ }^{2}$ \\ ${ }^{\mathbf{1}}$ Regional Educational Services, Open University of Sri Lanka \\ ${ }^{2}$ Department of Management Studies, Open University of Sri Lanka \\ 1'renukapous1@gmail.com
}

\begin{abstract}
Student satisfaction in Open Distance Learning $(O D L)$ is a widely researched and admired feature in modern world. There are enormous number of research studies done on this ground with different variables affecting the student satisfaction. Since the Learners are coming from different societies, cultures, family backgrounds, educational backgrounds with different information technology skills it is very difficult to fulfill their requirements for satisfaction. But it must be explicable that the competitiveness of higher education rivalry being in the higher education field. The purpose of this study was to find out the significant factors affecting student satisfaction in Open distance learning at the Open University of Sri Lanka (OUSL). Based on literature, the famous modified service quality (SQ) model of SERVQUAL was applied in this study. The independent variables were Assurance, Empathy, Responsiveness, Reliability, and Website Content and the dependent variable was Student Satisfaction. Data were collected by using a self-administered questionnaire from 244 undergraduate students of OUSL. The analysis was based on descriptive and inferential statistics. The results have revealed Assurance, Reliability, and Website content in ODL were statistically significant with student satisfaction in ODL and results would contribute to administration of OUSL to improve the quality of service process.
\end{abstract}

Keywords: Student Satisfaction, Open Distance Education, Service Quality (SQ), Validity Test, Reliability Test

\section{Introduction}

Student satisfaction in Open Distance Learning (ODL) has become a key factor in successful completion of distance learning study programs, with the increasing demand for distance learning as a result of limitations in formal higher education. Distance learning environment is created when the student and teacher are separated from transactional distance or by loss of the face to face relationship (Moore, 1993; Moore and Kearsley, 2011).This has created challenges to keep pace with advances in technology and practices (Garrison, 2000). However, this particular communication and psychological space between teachers, learners, and technology must be considered as different interaction issues (Gunawardena, 1999; Mbwesa, 2014; Moore, 1989, 1996). Key interactions are student-instructor followed by student-content, student-student, and student-technology, but it has not focused with the number of times of interaction (Moore \& Kearsley, 1996). Researchers have further revealed the impact of quality to resolve the learning problems of distance learners. The target output in ODL has faced the challenge of increasing of non-completion rate, which leads to high student attrition or dropout. In March 2010, Simpson argued " Does 
distance education does more harm than good?" and revealed the status of the Open University of United Kingdom (UK), the dropout for new students around $45 \%$ and nearly to graduation 80\%. In 2013 Simpson has showed how the students were progressing and dropping out from a UK foundation program by using a river diagram.

To avoid dropouts in this learning process, the quality procedures must be introduced as a continuous process. There is a critical link in between student retention and the quality of service in open and distance learning (Chakuchichi, 2011). Open University of Sri Lanka too has faced the same situation with high enrollment rate of students and low completion rate which will lead to a high dropout rate (Statistical Handbook 2013, 2014; Strategic Management Plan 2015 - 2020, 2014). It is evident from the service quality literature, there are vast number of studies empirically found the factors which are affecting critically and the various levels for the learner's perceived quality and satisfaction in open distance education system (Chakuchichi, 2011; Kuo \& Ye, 2009; Peterson, Kovel-Jarboe, \& Schwartz, 1997).

\subsection{Problem Statement}

The Open University of Sri Lanka offers Open Distance Learning to the nation from 1980 in order to fill the gap in limited formal higher education opportunities. But the graduation rate from OUSL is not proportionately increased with the increase of enrollment in ODL in Sri Lanka. The total enrollment and output figures of students from year 1982 to 2013 are shown in Table 1 and Table 2 below. They clearly show the gap between enrollment and passing out of students (Statistical Handbook - 2013, 2014).

Table 01: Total Student Enrollment and Output from Year 1982-2000

\begin{tabular}{|c|c|c|c|c|c|}
\hline Year & $\begin{array}{c}\text { Total Student } \\
\text { Enrollment }\end{array}$ & $\begin{array}{l}\text { Total Student } \\
\text { Output }\end{array}$ & Year & $\begin{array}{c}\text { Total Student } \\
\text { Enrollment }\end{array}$ & $\begin{array}{l}\text { Total Student } \\
\text { Output }\end{array}$ \\
\hline 1982 & 3999 & 733 & 1991 & 14763 & 1996 \\
\hline 1983 & 7611 & 1689 & 1992 & 16286 & 2213 \\
\hline 1984 & 6457 & \multirow{2}{*}{1256} & 1993 & 16757 & 1077 \\
\hline 1985 & 9279 & & 1994 & 19529 & 1826 \\
\hline 1986 & 10167 & 1490 & 1995 & 18473 & 2186 \\
\hline 1987 & 13119 & 1646 & 1996 & 16948 & 1934 \\
\hline 1988 & 13197 & 812 & 1997 & 16989 & 2379 \\
\hline 1989 & 13355 & \multirow{2}{*}{5612} & 1998 & 17013 & 2402 \\
\hline 1990 & 14702 & & 1999 & 17234 & 2215 \\
\hline & & & 2000 & 18744 & 1917 \\
\hline
\end{tabular}


Table 02: Total Student Enrollment and Output from Year 2001-2013

\begin{tabular}{|l|l|l|}
\hline Year & $\begin{array}{c}\text { Total Student } \\
\text { Enrollment }\end{array}$ & $\begin{array}{c}\text { Total Student } \\
\text { Output }\end{array}$ \\
\cline { 1 - 2 } 2001 & 19385 & \multirow{2}{*}{4571} \\
\hline 2002 & 21110 & 2565 \\
\hline 2003 & 23508 & \multirow{2}{*}{4045} \\
\hline 2004 & 24692 & \\
\hline 2005 & 24373 & \multirow{2}{*}{4642} \\
\hline 2006 & 24846 & 2832 \\
\hline 2007 & 25251 & 4104 \\
\hline 2008 & 27121 & 4553 \\
\hline 2009 & 26395 & 2744 \\
\hline 2010 & 30469 & 6218 \\
\hline 2011 & 34095 & 6155 \\
\hline 2012 & 35647 & \\
\hline 2013 & 38294 & \\
\hline
\end{tabular}

There will be many reasons for this situation (Ariadurai \& Manohanthan, 2008; De Zoysa, Munasinghe, Seneviratne, \& Mukunthan, 2011; Ismail, August 1997; Munro, 1987; Lekamge, Ranawake, Gunaratne, \& Jayananda, 1999; Tinto, 2006-2007). Researchers have empirically proven that the service quality offered by the institution and perceived by the students which will lead to student satisfaction or dissatisfaction may be one of a close reason (Jurkowitsch, Vignali, \& Kaufmann, 2006). Based on the findings of previous studies, to explore the relationship between service quality and student satisfaction in Sri Lankan ODL environment is the problum of this study.

\subsection{Research Questions}

The research questions were framed based on the problem statement and the dimensions of service quality enlighten from literature. These questions mainly concentrate dimensions of modified SERVQUAL model (Stodnick \& Rogers, 2008 ; Udo, Bagchi, \& Kirs, 2011). The dimensions of SERVQUAL; Assurance, Empathy, Reliability, Tangibility, and Responsiveness have been used to find out the student satisfaction in higher education (Stodnick \& Rogers, 2008). Research questions are as follows:

i. Is there any association between Assurance in perceived service quality and Student Satisfaction in ODL in Sri Lanka? 
ii. Is there any association between Empathy in perceived service quality and Student Satisfaction in ODL in Sri Lanka?

iii. Is there any association between Responsiveness in perceived service quality and Student Satisfaction in ODL in Sri Lanka?

iv. Is there any association between Reliability in perceived service quality and Student Satisfaction in ODL in Sri Lanka?

v. Is there any association between Web Site Content in perceived service quality and Student Satisfaction in ODL in Sri Lanka?

\subsection{Research Objectives}

1. To examine the factors affecting the service quality of ODL towards Student Satisfaction in Sri Lanka (SL).

2. To fitting a model to estimate the probability of student satisfaction based on service quality of ODL in Sri Lanka.

\subsection{Significance of the Study}

This study enlightens the path for the academia in ODL in SL higher management and policy makers to make the necessary amendments in course development, course curriculum, and technological enhancement to attract more learners who are satisfied with the service. Even disables and disadvantaged suburban learners could be attracted to ODL with improved service quality after addressing the significant factors on student satisfaction.

\section{Literature Review}

\subsection{ODL and Service Quality}

The service quality is defined for this study as interaction between student and service Organization (Stodnick and Rogers, 2008). Udo, Bagchi, \& Kirs have used modified SERVQUAL to assess the perceived service quality of e-learning in distance education in 2011 and four out of the five dimensions (except Reliability) play a significant role. In 2012, Mantovani has used the same and only Assurance, Reliability and Web site content in pereived service quality in Distance learning were significant. But they have not applied modified SERVQUAL to access the relationship with student satisfaction in distance learning.

\subsection{Student Satisfaction}

Student satisfaction is defined for this study based on Udo, Bagchi,and Kirs, 2011 as "overall assessment of the student learning experience". In 2008 Stodnick and Rogers have used SERVQUAL scale to a traditional classroom in the U.S.A and revealed Empathy, Reliability and Assurance dimensions were positively related with student satisfaction with their course and instructors. This innovative approach has attempted 
to bridge the gap of well-validated and widely used service operations construct to access student perceived service quality and satisfaction in the educational environment. In 2011, Wei and Ramalu have examined the relationship between service quality and student satisfaction in university of Malaysia using SERVQUAL instrument and found Responsiveness, Assurance and Empathy were significant with the student satisfaction. Hasan, Ilias, Rahman and Razak (2008) have attempted to examine the relationship between SERVQUAL and students satisfaction in two universities in Malaysia and revealed all 5 dimensions were positively significant with student satisfaction. In 2014 by applying SERVQUAL to private universities and colleges in Malaysia Mansori, Vaz and Ismail concluded that Tangibility, Empathy, and Responsiveness were significant. Sembiring in 2014 in Indonesia has examined overall service quality with student satisfaction in an ODL mode by using SERVQUAL and discerned that Reliability, Responsiveness, and Empathy were significant empirically .

\subsection{Service Quality (SQ)}

The SERVQUAL instrument which has generated by a great attention in last 50 years (Basiony, Alla, and Sayed, 2014). The most remarkable contribution towards the measurement of service quality by Parasuraman, Zeithaml and Berry in 1985 and 1988 with "gap model of service quality" and SERVQUAL. Many studies were found in different fields other than education; Mohammad and Alhamadani(2011) in banking in Jordan with all dimensions, Ioannis and Constantine(2009) in health care in Greece except Reliability with all dimensions, Lee, Chen, Huang, Chang, \& Udomjarumanee (2009) in real estate brokerage firms in Thailand and Taiwan with all dimensions, Basiony, Alla and Sayed (2014) in tourism with all dimensions and Olorunniwo \& Hsu (2006) in mass service category of retail bank with all 5 constructs. It can be concluded that in higher education and other industries have heavily applied the instrument of SERVQUAL while very little have addressed in an open distance learning environment. This study would be addressed the gap of application of modified SERVQUAL instrument and the relationship of student satisfaction in ODL environment of OUSL.

\section{Methodology}

Modified SERVQUAL, five dimensions were considered as independent variables and student satisfaction was taken as the dependent variable. Five dimensions were Assurance, Empathy, Responsiveness, Reliability, and Website content. The population for this research was the undergraduate students registered for the academic year 2012/2013 which was the highest enrollment recorded year. The Instrument was mainly based on literature (Stodnick \& Rogers,2008 ;Udo, Bagchi, \& Kirs , 2011) and minor modifications were made. The scale of the research instrument except the demographic questions rated with 5-point Likert scale with 1-Strongly 
Disagree to 5-Strongly Agree. The Primary data collection method was survey with a self-administered questionnaire with 43 questions which have validated and tested for reliability and validity in the pilot survey. Four main regional centres were randomly selected out of 8 centres in the OUSL and responses were the 244 undergraduate students who have more than one-year learning experience and using of university services. Data analysis consists with descriptive and inferential statistics. Inferential statistics consists of Spearman rank correlation to test the association of variables and ordinal logistic regression for model fitting. Logistic regression analysis is the non parametric counter part of multiple regression analysis which is applicable when the response variable is measured in Nominal or Ordinal scale (Konarasinghe, 2010; Thattil, 1999). Nonparametric implies that there is no assumption of the specific distribution of the population. Non-parametric test results are more robust against the violation of the assumptions (Field, 2009, pp 264-315; Konarasinghe, 2010, pp 49-53; Saunders, Lewis, \& Thornhill, 2009, pp 449-453). The ordinal logistic model used in this study as follows.

$$
\ln \left[\frac{p_{i}}{1-p_{i}}\right]=\alpha+\beta_{1} X_{1}+\beta_{2} X_{2}+\beta_{3} X_{3}+\beta_{4} X_{4}+\varepsilon
$$

Where; $\mathrm{Y}=$ Student satisfaction in open distance education in OUSL,

$\begin{array}{ll}\mathrm{X}_{1}=\text { Assurance in ODL in OUSL } & \mathrm{X}_{2}=\text { Empathy in ODL in OUSL } \\ \mathrm{X}_{3}=\text { Responsiveness in ODL in OUSL } & \mathrm{X}_{4}=\text { Reliability in ODL in OUSL } \\ \mathrm{X}_{5}=\text { Website content in ODL in OUSL } & \varepsilon=\text { Random error. } \\ \mathrm{P}_{\mathrm{i}}=\text { Proportion of success } & \end{array}$

Five hypotheses were tested.

1. $\mathbf{H}_{1}$ : There is an association between Assurance of perceived service quality and student satisfaction in ODL in Sri Lanka.

2. $\mathbf{H}_{2}$ : There is an association between Empathy of perceived service quality and student satisfaction in ODL in Sri Lanka.

3. $\mathbf{H}_{3}$ : There is an association between Responsiveness of perceived service quality and student satisfaction in ODL in Sri Lanka.

4. $\mathbf{H}_{4}$ : There is an association between Reliability of perceived service quality and student satisfaction in ODL in Sri Lanka.

5. H5: There is an association between Web site content of perceived service quality and student satisfaction in ODL in Sri Lanka.

\section{Data Analysis and Results}

The validity and reliability tests could be considered as main evaluation methods of the measurement instrument and Cronbach coefficient alpha is the most widely used test for reliability analysis (Fields \& Bisschoff, 2014). Validity is concerned to what 
extent an instrument measures that intended to measure and Reliability is the ability of an instrument to measure consistently (Tavakol \& Dennick, 2011). The CronbachAlpha value of all the constructs were more than 0.71 and can be considered as acceptable level (Nunnally, 1978). The Kaiser-Meyer-Olkin (KMO) is used to measure the sampling adequacy of the survey constructs and the values more than 0.7 could be considered as good (FIELD, 2009,p.647). For this study the KMO values were tabulated in Table 1.

Table 01: Reliability and Validly

\begin{tabular}{l|l|l|l|l|l}
\hline & Assurance & Empathy & Responsiveness & Reliability & $\begin{array}{l}\text { Web site } \\
\text { Content }\end{array}$ \\
\hline $\begin{array}{l}\text { Cronbach- } \\
\text { Alpha }\end{array}$ & 0.715 & 0.836 & 0.848 & 0.769 & 0.873 \\
\hline KMO value & 0.759 & 0.808 & 0.872 & 0.807 & 0.840 \\
\hline No. of items & 7 & 6 & 6 & 7 & 8 \\
\hline
\end{tabular}

\subsection{Descriptive Statistics}

The analysis of the survey revealed that there were $67.5 \%$ of students agree with service quality dimension of Assurance in perceived service quality in ODL at OUSL and $40.2 \%, 42.7 \%, 46.7 \%, 35.2 \%$ and $54.5 \%$ of students agree with Empathy, Responsiveness, Reliability and Web site Content respectively. Descriptive summary available in table 02 .

Table 02: Summary of Descriptive Statistics

\begin{tabular}{l|l|l|l}
\hline \multicolumn{1}{c|}{ Construct } & Agreed \% & Disagreed \% & Neutral\% \\
\hline Assurance & 67.5 & 13.9 & 18 \\
\hline Empathy & 40.2 & 33.2 & 26.6 \\
\hline Responsiveness & 42.7 & 28.7 & 28.7 \\
\hline Reliability & 46.7 & 25.0 & 28.3 \\
\hline Web site Content & 35.2 & 34.4 & 30.3 \\
\hline Satisfaction & 54.5 & 27.4 & 18.0 \\
\hline
\end{tabular}

\subsection{Inferential Statistics}

Spearman's rank Correlation results show that $\mathrm{P}$ values of correlation between $\mathrm{Y}$ and $\mathrm{X}_{1}, \mathrm{X}_{2}, \mathrm{X}_{3}, \mathrm{X}_{4}$ and $\mathrm{X}_{5}$ were less than 0.05 ( $\left.\mathrm{P}<0.05\right)$. It clearly shows that there is a significant relationship between $\mathrm{Y}$ (satisfaction) in ODL and $\mathrm{X}_{1}, \mathrm{X}_{2}, \mathrm{X}_{3}, \mathrm{X}_{4}$ and $\mathrm{X}_{5}$. 
The correlation coefficient of all the variables were positive. It shows there is a positive association between $\mathrm{Y}$ and all independent variables (Table 3).

\section{Table 03: Correlations}

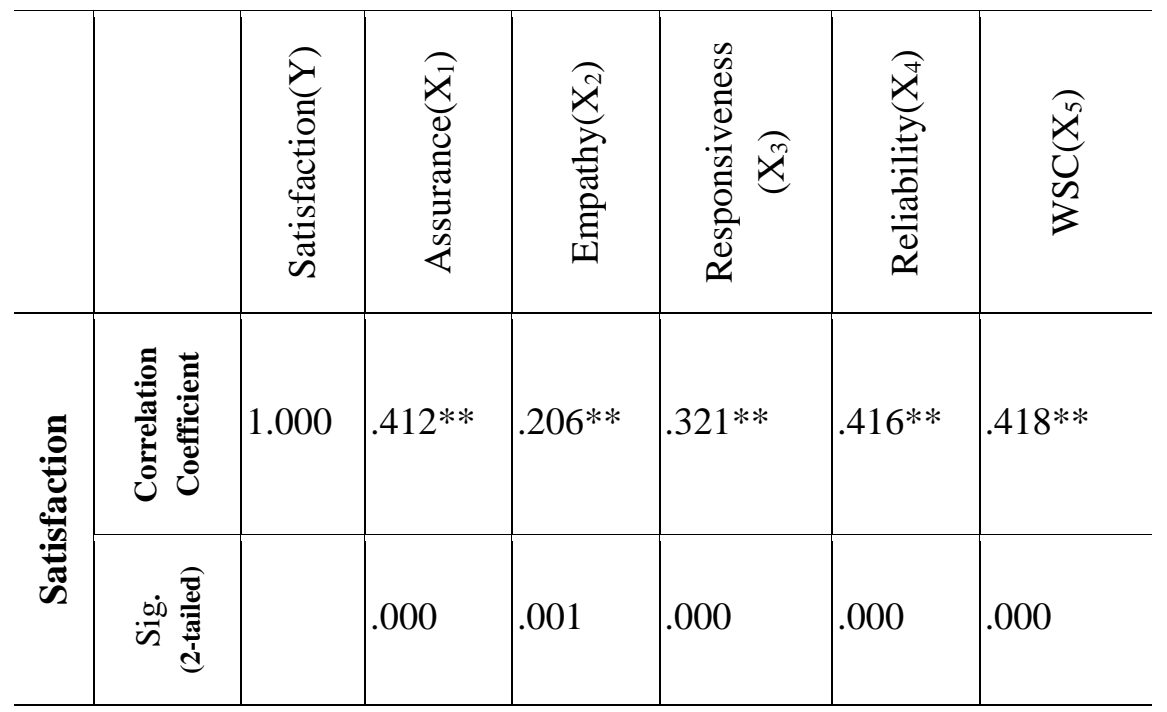

**. Correlation is significant at the 0.01 level (2-tailed).

The study was focused on model fitting. The Table 4 shows the results of ordinal logistic regression. It shows the individual coefficient of independent variables and their significance. Independent variables of Assurance, Reliability, and Web Site Content have obtained $\mathrm{P}$ values of $\mathrm{P}=0.000$ and $(\mathrm{P}<0.05)$. Therefore, these variables are significant in model fitting. But Empathy and Responsiveness in perceived service quality has obtained 0.171 and 0.912 respectively. It clearly shows the $\mathrm{P}$ value is greater than $0.05(\mathrm{P}>0.05)$. They are not significant in model fitting.

Table 05 shows the summary statistics of the ordinal logistic model (as recommended by Konarasinghe, 2010; Thattil, 1999).

The $\mathrm{P}$ value of log likelihood test (0.000) is less than the significance level of the test $(0.05)$. It shows that at least one regression coefficient is different from zero. It was concluded that regression coefficients are $\beta 1, \beta 4, \beta 5 \neq 0$. It is clear that there is a liner relationship between $\mathrm{Y}$ and $\mathrm{X}_{1}, \mathrm{X}_{4}$ and $\mathrm{X}_{5}$. Therefore, the model was fitted with variable $\mathrm{X}_{1}, \mathrm{X} 4$ and $\mathrm{X}_{5}$ given in Table 5 . 
Table 04: Results of Ordinal Logistic Regression

\begin{tabular}{l|l|c|c|c|l|l|l}
\hline \multicolumn{1}{c}{ Predictor } & Coef & SE Coef & $\mathbf{z}$ & $\mathbf{P}$ & \multirow{2}{*}{$\begin{array}{c}\text { Odds } \\
\text { Ratio }\end{array}$} & \multicolumn{2}{|c}{ 95\% CI } \\
\hline Const(1) & 2.09641 & 0.608566 & 3.44 & 0.001 & & & \\
\hline Const(2) & 4.71659 & 0.653590 & 7.22 & 0.000 & & & \\
\hline Const(3) & 5.76693 & 0.684892 & 8.42 & 0.000 & & & \\
\hline Const(4) & 8.97509 & 0.803588 & 1.17 & 0.000 & & & \\
\hline Assurance & -0.725422 & 0.169913 & -4.27 & 0.000 & 0.48 & 0.35 & 0.68 \\
\hline Empathy & 0.210914 & 0.154083 & 1.37 & 0.171 & 1.23 & 0.91 & 1.67 \\
\hline Responsiveness & -0.0170200 & 0.154083 & -0.11 & 0.912 & 0.98 & 0.73 & 1.33 \\
\hline Reliability & -0.583584 & 0.161819 & -3.61 & 0.000 & 0.56 & 0.41 & 0.77 \\
\hline Web Site Content & -0.712031 & 0.135534 & -5.25 & 0.000 & 0.49 & 0.38 & 0.64 \\
\hline
\end{tabular}

The results of the model fitting are summarized in Table 5. The goodness of fit test used to see whether the model adequately fitted with the data set. Pearson and Deviance test are the goodness of fit tests used in logistic regression analysis. If the Pvalue of Pearson test and Deviance test are greater than $0.05(\mathrm{P}>0.05)$, that shows the model is adequately fitted with the data set. The results of the model fitting of this study shows, the P-value of Pearson test is 0.406 and P-value of the Deviance test 1.000. Both $P$ values are greater than the significance level. It was concluded that fitted model was adequately fitted with the data set.

Table 05: Summary Statistics of Ordinal Logistic Model

\begin{tabular}{c|c|c|c}
\hline $\begin{array}{c}\text { Log } \\
\text { likelihood G }\end{array}$ & $\begin{array}{c}\text { p value of Log- } \\
\text { Likelihood test }\end{array}$ & $\begin{array}{c}\text { p value } \\
\text { Pearson's test }\end{array}$ & $\begin{array}{c}\text { p value } \\
\text { Deviance test }\end{array}$ \\
\hline 104.650 & 0.000 & 0.406 & 1.000 \\
\hline
\end{tabular}

\section{Conclusion}

The independent variables of Assurance of perceived service quality in ODL followed by Reliability, and Web Site Content were significant with student satisfaction in ODL environment in OUSL. This results support with the study of Stodnick and Rogers (2008). Correlation of all five variables were significant and all five research questions and hypotheses were supported with this study. Web Site Content of perceived service quality in ODL has the highest association and has added predictive power of the model in perceived service quality and student satisfaction in ODL at OUSL. But the 
independent variables of Assurance, Reliability, and Web Site Content were only fitted in the model (equation 2).

$$
\ln \left[\frac{p_{i}}{1-P_{i}}\right]=5.388755-0.725422 X_{1}-0.583584 X_{4}-0.712031 X_{5}
$$

\section{Recommendations}

It is recommended to give due consideration to the findings of this study in curriculum or course development, technology development or any other improvements in ODL programs in the view of improving the student satisfaction which will ultimatelty lead to better completion rate of ODL programs and result will be the better output rate. It is recommended to increase the sample size and select more variables to more reflect the student satisfaction in an open distance education environment. Further, it is more comprehensive if postgraduate students also included in the study.

\section{References}

Ariadurai, S. A., \& Manohanthan, R. (2008, June). Instructional Strategies in Teaching Engineering at a Distance: Faculty Perspective. The International Review of Research in Open and Distance Learning, 9(2), 1-6. Retrieved 07 29, 2015, from http://www.irrodl.org/index.php/irrodl/article/view/461/1046

Basiony, A. E., Alla, G. A., \& Sayed, A. s. (2014). Munich Personal RePEc Archive. Evaluating Tourism Service Quality Provided to the European Tourist Applied on the British tourist. suez canal university. Retrieved April 29, 2015, from http://mpra.ub.unimuenchen.de/57164/1/MPRA_paper_57164.pdf

Chakuchichi, D. (2011). Student Retention as a Function of the Quality of Learner Support in Open and Distance Learning: Students' Perceptions at the Zimbabwe Open University. Zimbabwe International Journal of Open \& Distance Learning, 1(1), 90-98.

De Zoysa, T. S., Munasinghe, D. M., Seneviratne, P., \& Mukunthan, T. (2011). Study on Student Dropout in Advanced Certificate in Pre School Education Programme in the open university of Sri Lanka. Annual Academic Session. Open University of Sri Lanka.

Field, A. (2009). Discovering Statistics Using SPSS (and sex and drugs and rock 'n' roll) Third Edition. SAGE.

Fields, Z., \& Bisschoff, C. (2014). Comparative analysis of two conceptual frameworks to measure creativity at a university. Problems and Perspectives in Management, 12(3), 46-58.

Garrison, R. (2000, June). Theoretical Challenges for Distance Education in the 21st Century: A shift from structural to transactional issues. International Review of Research on Open and Distance Learning, 1(1). Retrieved 09 12, 2014, from http://www.irrodl.org/index.php/irrodl/article/view/2/333 
Gunawardena, C. (1999). The Challenge of Designing and Evaluating "Interaction" in WebBased Distance Education. Web Net 99 World Conference on the WWW and Internet Proceedings (Honolulu, Hawaii, October 24-30, 1999); (pp. 1-7). University of New Mexico. PMCid: PMC2269683

Hasan, H. F., Ilias, A., Rahman, R. A., \& Razak, M. Z. (2008, July). Service Quality and Student Satisfaction: A Case Study at Private Higher Education Institutions. International Business Research, 1(3), 163-175. Retrieved from www.ccsenet.org/journal.html

Ioannis, E. C., \& Constantine, L. (2009). Service quality effect on satisfaction and word of mouth in the health care industry", Managing Service Quality: An International Journal, 19(2), 229 - 242. Retrieved from http://dx.doi.org/10.1108/09604520910943206 http://dx.doi.org/10.1108/09604520910943206

Ismail, A. G. (1997 August). A critical study on factors influencing the student dropout from the educational programs offered by the Open University of Sri Lanka (Doctoral Thesis). Faculty of Education, University of Colombo, Sri Lanka.

Jurkowitsch, S., Vignali, C., \& Kaufmann, H.-R. (2006). A Student Satisfaction Model for Austrian Higher Education Providers Considering Aspects of Marketing Communications. Innovative Marketing, 2(3), 9-23.

Konarasinghe, K.M.U.B. (2010). Determinants of Demand for International Tourism Industry in Sri Lanka.MBA Thesis. Faculty of Management, Rajarata University of Sri Lanka

Kuo, Y.-K., \& Ye, K.-D. (2009). The causal relationship between service quality, corporate image and adults' learning satisfaction and loyalty: A study of professional training programs in a Taiwanese vocational institute. Total Quality Management \& Business Excellence, 20:7, 749-762. doi:10.1080/14783360903037085. http://dx.doi.org/10.1080/14783360903037085

Lee, Y.-J., Chen, C.-Y., Huang, C.-L., Chang, L.-Y., \& Udomjarumanee, K. (2009). A Comparison of Service Quality Perception in Real Estate Brokerage between Taiwan and Thailand. The Journal of International Management Studies, 4(3), 11-24.

Lekamge, G., Ranawake, G., Gunaratne, K., \& Jayananda, R. (1999). Student satisfaction with OUSL support services. OUSL Journal, 2(80). Retrieved from http://digital.lib.ou.ac.lk/docs/handle/701300122/46

Mansori, S., Vaz, A., \& Ismail, Z. M. (2014, March). Service Quality, Satisfaction and Student Loyalty in Malaysian Private Education. Asian Social Science, 10(7), 57-66. http://dx.doi.org/10.5539/ass.v10n7p57

Mantovani, D. M. (2012). Distance Education on the Stakeholders Perspectives: Student's, Instructor's and Administrator's Perspectives (Doctoral Dissertation). University of Sao Paulo, School of Economics, Business and Accounting, Business Department , Business Graduate Program. Retrieved 10 29, 2014, from www.teses.usp.br/teses/...07112012.../DaiellyMelinaNassifMantovani.pdf 
Mbwesa, J. K. (2014, April). Transactional Distance as a Predictor of Perceived Learner Satisfaction in Distance Learning courses: A case study of Bachelor of Education Arts Program, University of Nairobi, Kenya. Journal of Education and Training Studies, 2(2). doi:10.11114/jets.v2i2.291. http://dx.doi.org/10.11114/jets.v2i2.291

Mohammad, A. A., \& Alhamadani, S. Y. (2011). Service Quality Perspectives and Customer Satisfaction in Commercial Banks Working in Jordan. Middle Eastern Finance and Economics (14), 60-72. Retrieved from http://www.eurojournals.com/MEFE.htm

Moore, E. T. (1989). Editorial Three Types of Interaction. Retrieved 10 81, 2014, from http://aris.teluq.uquebec.ca/portals/598/t3_moore1989.pdf http://dx.doi.org/10.1080/08923648909526659

Moore, M. G. (1993). Theory of transactional distance. Retrieved 09 10, 2014, from http://www.c3l.uni-oldenburg.de/cde/support/readings/moore93.pdf

Moore, M. G., \& Kearsley, G. (1996). Chapter1 Fundamentals of Distance Education. In Distance Education A Systems View (pp. 1-18). Wadsworth Publishing Company.

Moore, M., \& Kearsley, G. (2011). Distance Education Systems View of Online Learning Third Edition. Retrieved 09 14, 2014, from http://www.cengagebrain.com.au/content/ moore20992_1111520992_02.01_chapter01.pdf

Munro, J. (1987). The Discourse of Dropout in Distance Education: A Theoretical Analysis. Paper presented at the Anual Conference of the Canadian Asociation for the Study of Ault Education (7th, Calgary, Alberta, Canada, May 1988, (pp. 1-11). Retrieved 0910 , 2014, from http://files.eric.ed.gov/fulltext/ED310752.pdf

Nunnally, J. C. (1978). Psychometric theory (2nd Ed.). McGraw-Hill, New York, NY.

Olorunniwo, F., \& Hsu, M. K. (2006). A typology analysis of service quality, customer satisfaction and behavioral intentions in mass services. Managing Service Quality, 16 (2), 106-123. doi: 10.1108/09604520610650600. http://dx.doi.org/10.1108/09604520610650600

Parasuraman, A., Zeithaml, V. A., \& Berry, L. L. (1985). A Conceptual Model of Service Quality and Its Implications for Future Research Author. The Journal of Marketing, 49(4, autumn), 41-50. Retrieved from http://www.jstor.org/stable/1251430 http://dx.doi.org/10.2307/1251430

Parasuraman, A., Zeithaml, V. A., \& Berry. L. L. (1988). SERVQUAL: A Multiple-Item Scale for Measuring Consumer Perceptions of Service Quality. Journal of retailing, 64(1) spring, 12-40.

Peterson, S. L., Kovel-Jarboe, P., \& Schwartz, S. A. (1997). Quality Improvement in Higher Education: implications for student retention, Quality in Higher Education. Quality in Higher Education, 3(2), 131-141. doi: 10.1080/1353832970030204 http://dx.doi.org/10.1080/1353832970030204

Saunders, M., Lewis, P., \& Thornhill, A. (2009). Research Methods for Business Students, Fifth edition. Pearson. 
Sembiring, M. G. (2014). Student satisfaction and persistence: Imperative features for retention in open and distance learning. In D. Wong, \& K. C. Yuen (Ed.), 28th Annual Conference of the Asian Association of Open Universities (AAOU 2014). (pp. 250258). Compiled and published by The Open University of Hong Kong, Hong Kong SAR, China.

Simpson, O. (2010, March). Does distance education do more harm than good? Retrieved 08 25, 2014, from http://www.94669.mrsite.com/USERIMAGES/Does\%20distance\%20 education $\% 20 \mathrm{do} \% 20 \mathrm{harm} . \mathrm{pdf}$

Simpson, O. (2013). Student retention in distance education: are we failing our students? Open Learning: The Journal of Open, Distance and e-Learning, 28(2), 105-119. Retrieved from http://dx.doi.org/10.1080/02680513.2013.847363. http://dx.doi.org/10.1080/02680513.2013.847363

Statistical Handbook 2013. (2014, July). Open University of Sri Lanka. Retrieved 02 08, 2015, from www.ou.ac.lk

Strategic Management Plan 2015 - 2020. (2014). The Open University of Sri Lanka. Retrieved from www.ou.ac.lk/publications/smp

Stodnick, M., \& Rogers, P. (2008, January). Using SERVQUAL to Measure the Quality of the Classroom Experience. Decision Sciences Journal of Innovative Education, 6(1), 115133. http://dx.doi.org/10.1111/j.1540-4609.2007.00162.x

Tavakol, M., \& Dennick, R. (2011). Making sense of Cronbach's alpha. International Journal of Medical Education, 2, 53-55. doi: 10.5116/ijme.4dfb.8dfd http://dx.doi.org/10.5116/ijme.4dfb.8dfd

Thattil, R. O. (1999). Handbook on Design and Analysis of experiments. Postgraduate Institute of Agriculture.

Tinto, V. (2006-2007). Research and Practice of Student Retention: What Next?*. J. College Student Retention, 8(1), 1-19. http://dx.doi.org/10.2190/4YNU-4TMB-22DJ-AN4W

Udo, G. J., Bagchi, K. K., \& Kirs, P. J. (2008). Assessing Web Service Quality Dimensions: The E- Servperf Approach. Issues in Information Systems, IX (2), 313-322.

Udo, G. J., Bagchi, K. K., \& Kirs, P. J. (2011). Using SERVQUAL to assess the quality of elearning experience. Computers in Human Behavior, 27, 12721283.doi:10.1016/j.chb.2011.01.009. http://dx.doi.org/10.1016/j.chb.2011.01.009

Wei, C. C., \& Ramalu, S. S. (2011). Students Satisfaction towards the University: Does Service Quality Matters? International Journal of Education, 3 (2: E15), 1-15. doi:10.5296/ije.v3i2.1065. http://dx.doi.org/10.5296/ije.v3i2.1065 